Krystyna PAWŁOWSKA

Politechnika Krakowska

\title{
KRAJOBRAZY ZARAZY
}

\section{Wprowadzenie}

Jedna z definicji krajobrazu (Myga-Piątek, 2001, s. 165-176), uznawana szczególnie przez architektów krajobrazu, mówi iż: „Krajobraz jest syntetycznym obrazem wszystkiego, co istnieje i co dzieje się w przestrzeni". Zatem pandemia spowodowana przez koronawirusa jest zjawiskiem, które musi być $\mathrm{i}$ istotnie jest dostrzegane $\mathrm{w}$ krajobrazie. Pandemia ta jest wydarzeniem o ogromnej wadze, nie dającym się porównać z niczym, co miało miejsce w ostatnim stuleciu. Jej znaczenie teraz - podczas jej trwania -i konsekwencje na przyszłość dotyczą i dotyczyć będą bardzo wielu dziedzin, wśród których następstwa krajobrazowe nie są z pewnością najważniejsze. Niemniej są i będą istnieć zarówno te bezpośrednie, jak te wtórne wynikające ze zmian w innych dziedzinach życia. Wydaje się, że domena, w której pokłosie pandemii w krajobrazie jest widoczne najwyraźniej i to natychmiast, podczas jej trwania, jest turystyka. Dlatego ten i inne aspekty problemu są z pewnością godne przebadania i przemyślenia.

\section{Antyczne pamiątki po epidemiach}

Zacznijmy jednak od krajobrazów zarazy, które pozostawiły po sobie poprzednie wielkie epidemie - krajobrazów rzeczywistych i tych uwiecznionych w sztuce. Zawsze były to wydarzenia niezwykłe przerażające i to zapewne bardziej niż współczesna pandemia lat dwudziestych dwudziestego pierwszego wieku. Były niezrozumiałe, przeto kojarzono je z interwencją Boga lub bogów. Jeden z pierwszych opisów zarazy pozostawił Homer w pierwszej części Iliady.

${ }^{1}$ Zgodnie z wolą autorki tekst nie został poddany redakcji językowej. 
Ledwie skończył, modlitwa doszła ucha Feba;

Wysłuchał go łaskawie, zstąpił gniewny z nieba

Z łukiem swoim, z kołczanem; na ramionach strzały

W bystrym biegu strasznymi szczęki przerażały.

Idzie jak noc posępny; siadł z dala, łuk spina:

Leci strzała i świszcząc powietrze rozcina.

Okropnym brzmiąc łuk jękiem psy strzela i muły;

Wnet zgubne jego razy Achaje poczuły

Palą się bezprzestannie smutne trupów stosy.

Dlatego między nami zaraza się szerzy,

I nie wprzódy się w swoim gniewie Feb uśmierzy,

Aż król powróci zdobycz, którą dotąd trzyma.

I darmo odda brankę z czarnymi oczyma.

Gdy do Chryzy poślemy jeszcze stugłów święty,

Może się da złagodzić dla nas bóg zawzięty (Homer, 1804).

Pomór, jaki spadł na Achajów oblegających Troję, miał być karą za czyn Agamemnona, który odebrał kapłanowi Apolla Chryzesowi córkę i uczynił $\mathrm{z}$ niej brankę. Zaraza przedstawiana była jako strzały z łuku miotane w kierunku ludzi i zwierząt. Scenę tę uwiecznił Stanisław Wyspiański w swym cyklu 11 rysunków do Iliady, tłumaczonej przez Lucjana Rydla (fot. 1).

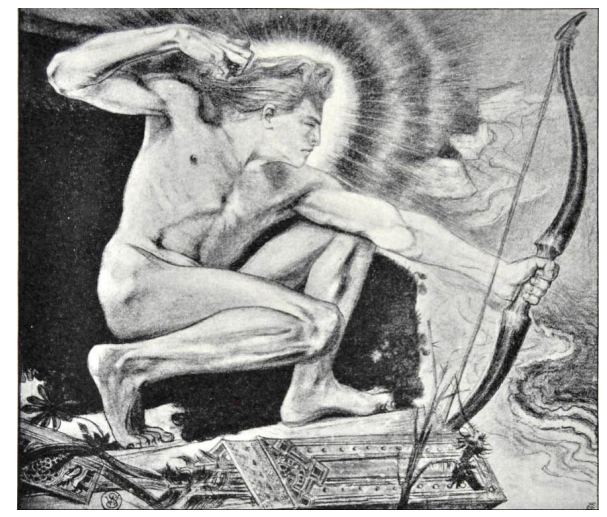

Fotografia 1. Apollo razi grotami pomoru, S. Wyspiański (1903) Źródło: Wikipedia (2021a)

Jest także inny antyczny opis zarazy - mniej poetycki, lecz obszerniejszy i zawierający mnóstwo szczegółowych informacji. Jest to Wojna peloponeska Tukidydesa. Wojna ta toczyła się między Atenami i Spartą w latach 431-404 p.n.e. Towarzyszyła jej wielka epidemia, prawdopodobnie dżumy. Zaraza ta zdziesiątkowała ludność Aten i podcięła pomyślny rozwój tego 
państwa-miasta. W opisie przebiegu i skutków choroby nie ma wielu wzmianek na temat krajobrazu, ale dowiadujemy się jednak, że: „trupy leżały stosami, chorzy tarzali się po ulicach i wokół źródeł na pół żywi z pragnienia. Także świątynie, gdzie mieszkali, pełne były trupów; ludzie umierali tam na miejscu" (Tukidydes, 1957, s. 116 ).

Ślady po antycznych epidemiach pozostały nie tylko w literaturze, ale także bezpośrednio $\mathrm{w}$ krajobrazie. Wiążą się one z postacią greckiego Asklepiosa i jego rzymskiego odpowiednika Eskulapa. Był to mityczny bóg sztuki lekarskiej. Przedstawiano go jako węża lub z wężem. Budowano mu świątynie, które miały nie tylko funkcję religijną. W niektórych przypadkach świątynie te rozrosły się do znacznych rozmiarów i odgrywały rolę antycznych ośrodków leczniczych. Był tam dostęp do wody, cienisty portyk dla chorych czekających na leczenie, były też budynki szpitalne, hospicja, sanatoria, lecznicze źródła wody, oliwne gaje itp. Relikty największego tego typu założenia nazywanego Asklepiejonem znajdują się na wyspie Kos (Asklepiejon na Kos, 2021). Zachowane do dziś relikty tego ośrodka pokazuja że było to par excellence wielkie założenie krajobrazowe rozłożone na stoku, z dalekim widokiem na morze. Sama lokalizacja w pięknym, pełnym powietrza krajobrazie wydaje się dobrze służyć zdrowiu (fot. 2).

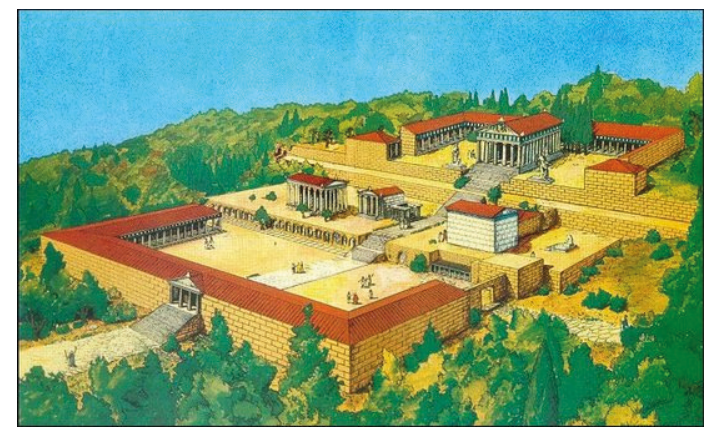

Fotografia 2. Rekonstrukcja założenia Asklepiejonu na greckiej wyspie Kos Źródło: Grekoman (2021)

Był także Asklepiejon w Rzymie na wyspie na Tybrze (fot. 3). Pomysł lokalizowanie ośrodków leczenia na wyspie, w izolacji od miasta, został potem wiele razy powtórzony $\mathrm{w}$ różnych czasach i różnych częściach świata, np. North and South Brother Islands w Nowym Jorku. Obecnie na wyspie tyberyjskiej jest średniowieczny szpital bonifratrów i barokowa Bazylika św. Bartłomieja, a więc funkcja medyczna miejsca była kontynuowana. 


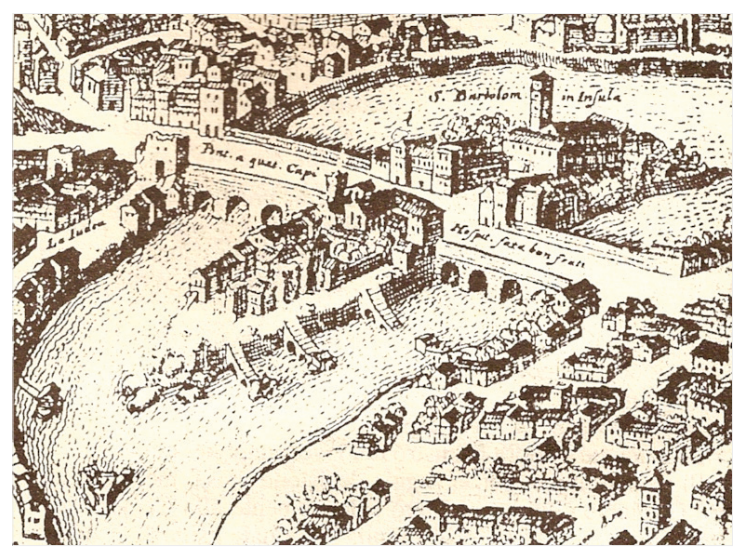

Fotografia 3. Wyspa Tyberyjska w Rzymie Źródło: Wikiwand (2021)

\section{3. Średniowieczne i nowożytne przedstawienia zarazy}

Epidemia, zaraza, mór, pomór, plaga, czarna śmierć, morowe powietrze czyli epidemie jako zjawiska nie tylko zabójcze lecz także wywołujące silne emocje i skłaniające do niecodziennych refleksji, były chętnie podejmowanym tematem sztuki i literatury (Sznajderman, 1994; Defoe, 1993; Krukowski, 2020), Defoe także średniowiecznej i nowożytnej. Obrazy i ryciny dotyczące tego tematu to przede wszystkim alegoryczne przedstawienia zarazy. Zaraza była na ogół kobietą odzianą w powłóczyste szaty, otulona chusta, niekiedy uskrzydlona. Towarzyszyły jej kościotrupy, często z kosami. Zarazę symbolizowali także mężczyźni, często na koniach, jak jeźdźcy Apokalipsy, podobnie jak Apollo miotający z łuku strzały zarazy (fot. 4). Wśród charakterystycznych postaci epidemii zapewne najpopularniejsza to doktor Schnabel z Rzymu ubrany w strój ochronny w kapeluszu i z maską w kształcie ptasiego dzioba (fot. 5). Ten rodzaj maski, ozdobiony bogatą dekoracją, jest wciąż używany podczas słynnych karnawałów weneckich i sprzedawany jako pamiątka z tego miasta.

Powodowani strachem przed zarazą ludzie modlili się, szczególnie do tych świętych, których charyzmat polegał na opiekowaniu się ofiarami zarazy. Byli to święci: Roch, Sebastian, Rozalia, Franciszek Salezy, Andrzej Bobola i wielu innych. W tłach obrazów przedstawiających te postacie odnaleźć można różne wyobrażenia krajobrazowe. Są to krajobrazy zniszczone, puste, przerażające i napełniające grozą (fot. 6, 7). 


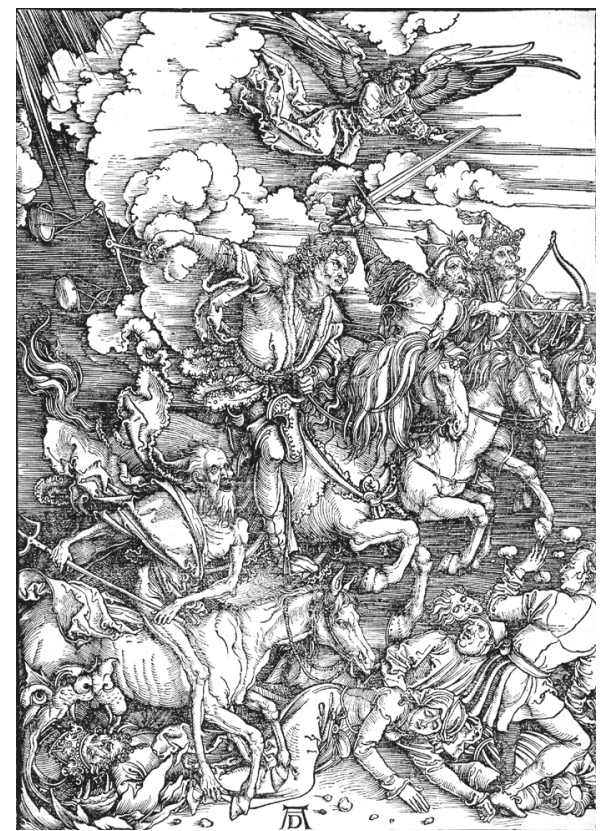

Fotografia 4. Czterej jeźdźcy Apokalipsy, A. Dürer (1496-1498) Źródło: Wikipedia (2021b)

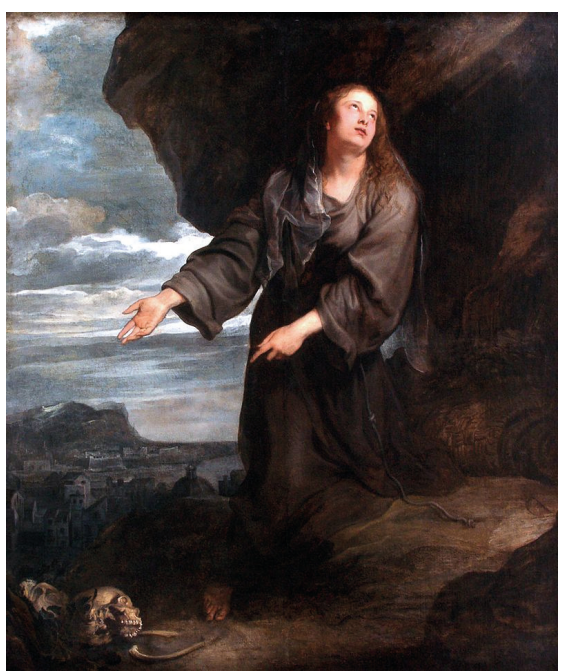

Fotografia 6. Św. Rozalia $z$ Palermo,

A. van Dyck (1629)

Źródło: Wikipedia (2021c)

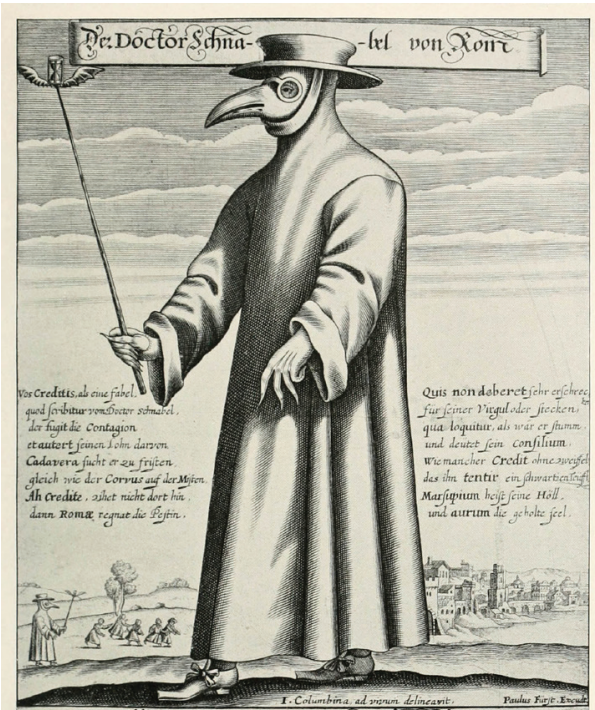

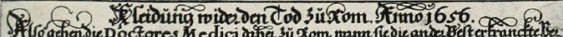

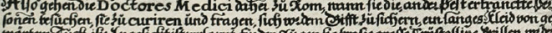

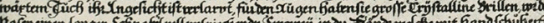

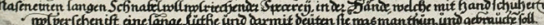

Fotografia 5. Der Doctor Schnabel von Rom, P. Fürst (1656)

Źródło: Wikimedia Commons (2021)

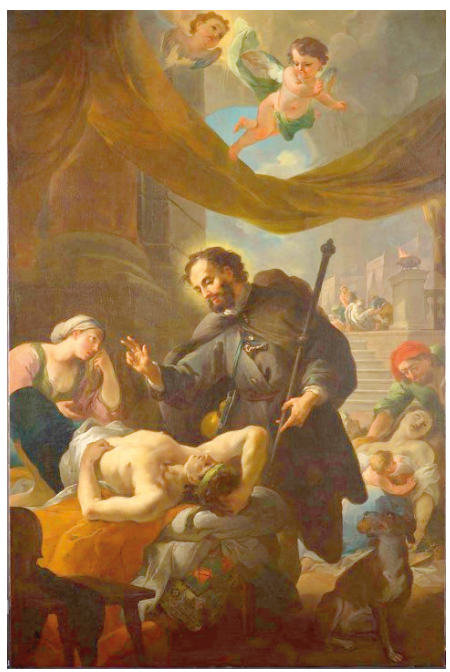

Fotografia 7. Św. Roch odwiedzajacy chorych, M. Altomonte (1719) Źródło: Niezależna (2021) 
Jednym z obrazów, w którym krajobraz nie jest tylko mało znaczącym tłem lecz ważną scenerią wydarzeń, jest Triumf śmierci Pietera Bruegela starszego, datowany na 1562 r. (fot. 8). Na pierwszym planie przedstawiona jest bitwa między armią kościotrupów a ludźmi, która nieuchronnie kończy się masową śmiercią tych ostatnich. Obraz interpretowany jest różnie: jako przedstawienie scen pomoru lub jako zapowiedź wojny. Krajobraz stanowiący scenerię tej bitwy jest pusty, wypalony, beznadziejnie smutny $z$ horyzontem zasnutym dymami i rozświetlonym łunami pożarów. Z punktu widzenia artystycznego jest to mistrzowskie, krajobrazowe przedstawienie tragedii - pejzaż ziejący pustką i niejako bezpłodny.

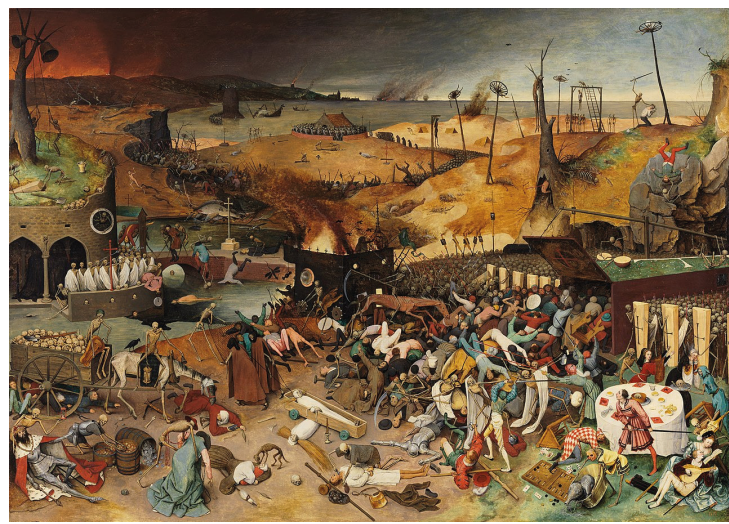

Fotografia 8. Triumf śmierci, P. Bruegla (starszy) (1562) Źródło: Wikipedia (2021d)

Usiane trupami miejsca, kościotrupy z kosami, anioły śmierci to przedstawienia dość często pojawiające się w europejskim malarstwie średniowiecznym i nowożytnym. Danse macabre - makabryczny taniec ludzi różnych nacji, wieku, płci, zawodów razem z kościotrupami miał wskazywać na równość ludzi wobec śmierci (fot. 9). Pejzażowa alegoria śmierci to temat znacznie rzadziej przedstawiany, dlatego obraz Bruegla jest tak niezwykły.

Znacznie częściej niż krajobrazy otwarte z piętnem zarazy, pojawiają się w malarstwie wnętrza krajobrazu miejskiego, stanowiące scenerię tragicznych zdarzeń. Pełno tu trupów leżących w bezładzie lub wiezionych gdzieś na wozach. Chorzy noszeni na noszach, zakapturzeni i zamaskowani lekarze czy inne służby miejskie bezskutecznie próbujące przeciwdziałać epidemii i przywracać życiu porządek. Można powiedzieć, że tragedia toczy się na ulicach i placach miasta. Nad tym chaosem polatują 


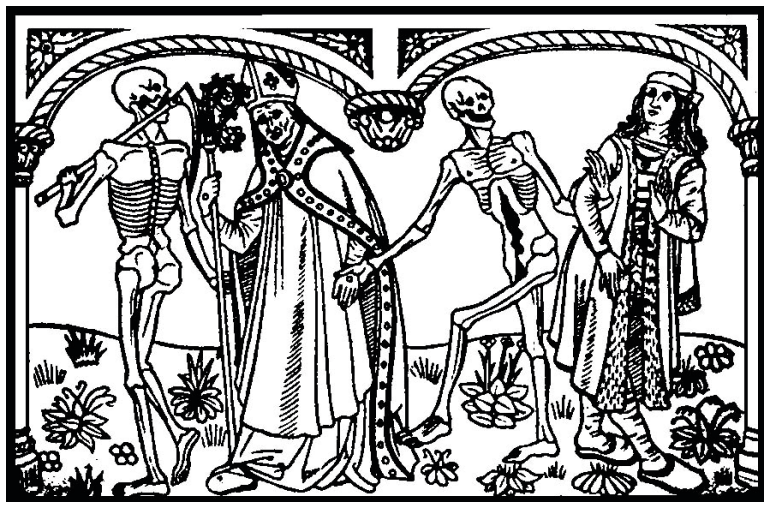

Fotografia 9. Danse macabre, G. Marchant (1486) Źródło: Wikipedia (2021e)

niekiedy aniołowie śmierci czy inne potworne wyobrażenia zarazy (fot. 10). W owych latach przyczyny epidemii nie były znane, toteż przedstawianie ich w realnej postaci nie było możliwe. Oprócz wspomnianych już personifikacji były też próby przedstawiania zarazy jako tchnienia wiatru czy też snującej się mgły lub płomieni o śmiercionośnej sile.

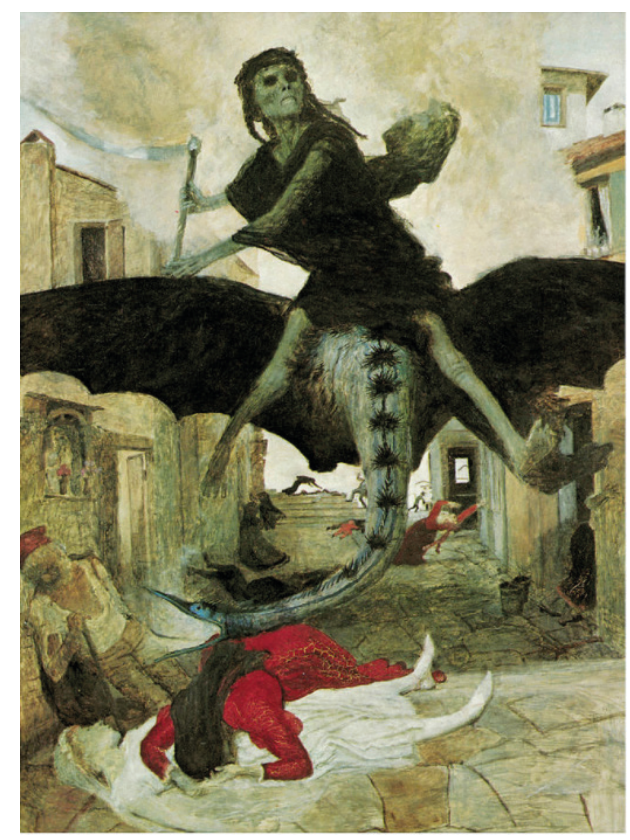

Fotografia 10. Zaraza, A. Böklin (1898) Źródło: Fineartamerica (2021) 


\section{Znaki zarazy w krajobrazie miejskim i otwartym}

Martwota i zniszczenie krajobrazu towarzyszące pomorom po ich zakończeniu powoli ustępowały. Krajobraz zabliźniał się, lecz na długo pozostawały pewne znaki tamtych czasów. Były to krzyże, figury świętych, słupy morowe, kapliczki przydrożne, latarnie umarłych, kolumny morowe itp. Ich celem pierwotnym była obrona przed zaraza, a potem uczczenie pamięci ofiar i dziękczynienie świętym patronom. Najbogatsze formy to tzw. kolumny morowe, czyli rodzaj pomnika w kształcie kolumny, słupa, obelisku czy piramidy, otoczonego licznymi figurami świętych i uwieńczone postacią Matki Boskiej lub grupą figur przedstawiającą Trójcę Świętą. Rozpowszechniły się w krajach byłej monarchii austro-węgierskiej, w tym w Czechach, Austrii, Słowacji, Słowenii, na Węgrzech (fot. 11). Powstawały w drugiej połowie XVI w. i w XVII w. Były to czasy rozkwitu baroku, a kolumny morowe stały się swoistą wizytówką tego stylu - znakiem epoki w krajobrazie miejskim. Stawiano je z reguły na głównych placach miast i miasteczek. W Czechach i na Słowacji to niemal obowiązkowy element tzw. náměstí, czyli głównego placu miasta. W Polsce stawiane były nie zawsze na rynku, lecz zawsze w ważnych węzłowych miejscach miasta, gdzie dawały się oglądać i gdzie

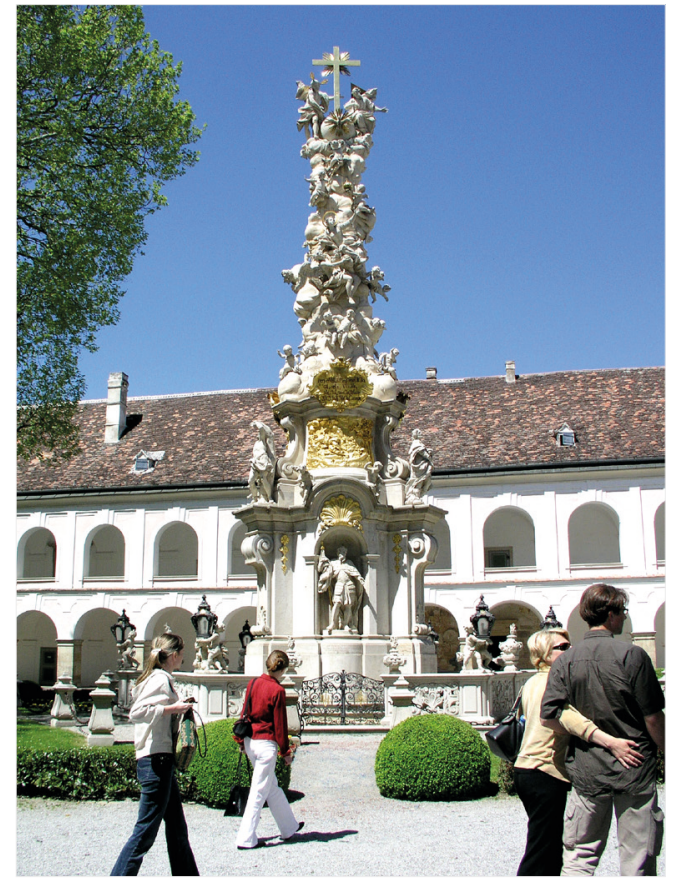

Fotografia 11. Heiligenkreutz, kolumna morowa na dziedzińcu klasztoru cystersów Źródło: K. Pawłowska 
można było gromadzić się na modlitwę. Przebogata forma rzeźbiarska, ozdobiona złoceniami, duża wysokość, eksponowane miejsce ustawienia - wszystko to sprawiało, że kolumny te pełniły rolę ważnych dominant krajobrazu miejskiego.

Na wsiach owe krzyże, kapliczki i kolumny ustawiane były w obrębie ogrodzenia kościoła, na rozstajach dróg, na placach, ale także w szczerym polu przy drodze (fot. 12). Często towarzyszyły im grupy drzew, czasem mini ogródek otoczony płotkiem. Rozmaitość tych form jest wielka Najpiękniejszy przykład z krajobrazowego punktu widzenia to z dala widoczna na fotografii 13 grupa drzew towarzysząca kapliczce, stanowiąca swego rodzaju bukiet ustawiony w eksponowanym miejscu.

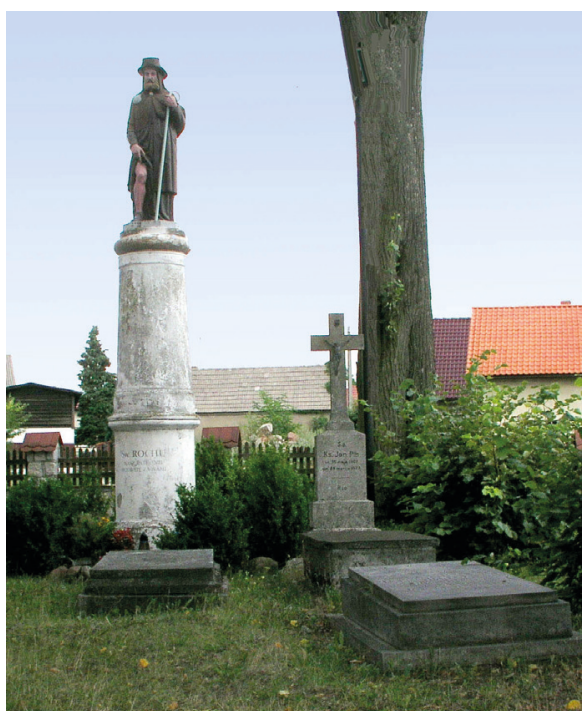

Fotografia 12. Kapliczka św. Rocha przy kościele w Osieku w Borach Tucholskich Źródło: K. Pawłowska

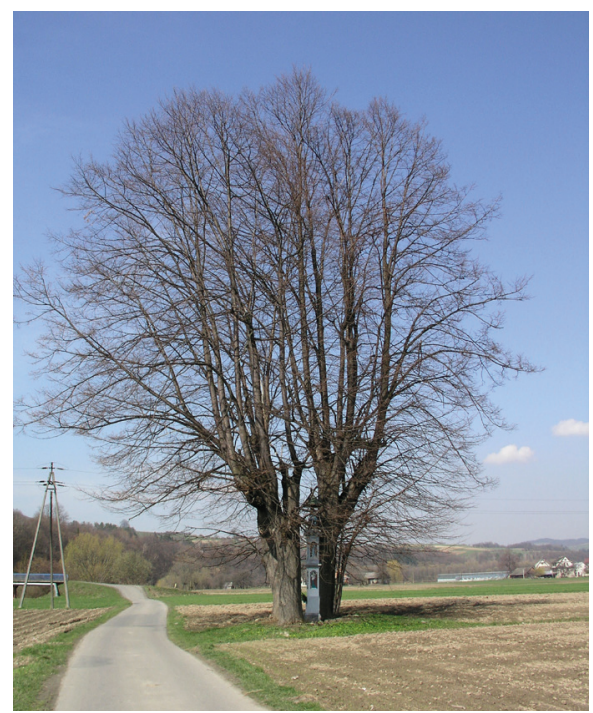

Fotografia 13. Kapliczka - bukiet w szczerym polu w Ujanowicach w Małopolsce

Źródło: K. Pawłowska

Innego rodzaju znakiem krajobrazowym są lepiej lub gorzej zachowane specjalne cmentarze dla ofiar epidemii. Aby zmniejszyć ryzyko zarażeń, umarłych chowano w zbiorowych mogiłach zlokalizowanych zwykle z dala od miejscowości. Miejsca takie ogradzano, zaznaczano krzyżami lub wznoszono tam mniejsze lub większe kapliczki (fot. 14). Cmentarze te, często na wzgórzu, nadal stanowią mocny akcent krajobrazowy, choć są na ogół zaniedbane, a ludzie, nawet miejscowi coraz rzadziej wiedza, czego są znakiem, co upamiętniają. 


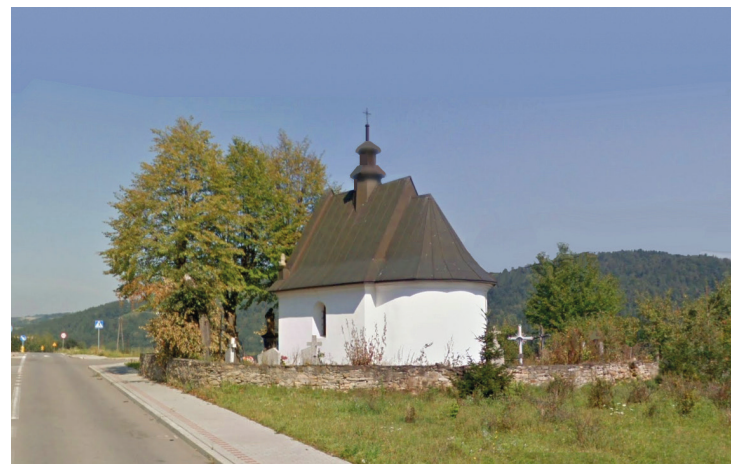

Fotografia 14. Kapliczka na byłym cmentarzu cholerycznym w Żbikowicach w Małopolsce Źródło: K. Pawłowska

Cmentarze epidemiczne urządzano także na wyspach - naturalnych miejscach izolacji. Bodaj najpiękniejszy taki cmentarz znajduje się w Wenecji na wyspie San Michele (fot. 15). Powstał z rozkazu Napoleona w 1807 r. Służył mieszkańcom Wenecji, a obecnie jako miejsce szczególnie piękne jest często nawiedzany przez turystów.

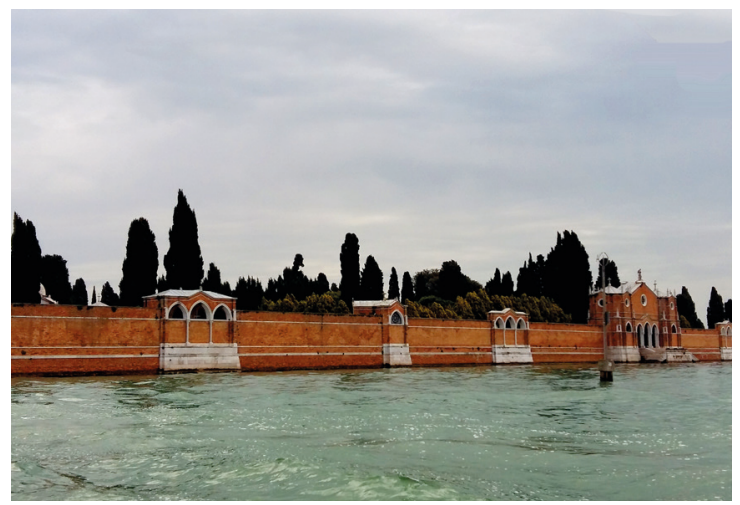

Fotografia 15. Wyspa-cmentarz w Wenecji Źródło: K. Pawłowska

Wraz z coraz lepszym rozumieniem natury epidemii i doskonaleniem sztuki zapobiegania i leczenia, obraz epidemii ulegał zmianom. Sceny epidemiczne w XIX w. coraz częściej są dokumentowane na fotografiach. Przedstawienia symboliczne ustępują realiom dzięki nowo zdobytej umiejętności odwzorowywania rzeczywistości na kliszy fotograficznej. Sceny toczą się już nie tyle na ulicach i placach miasta, lecz w szpitalach 
stałych i polowych, na ogół pod dachem. Wśród chorych i trupów nie kręcą się już następcy doktora Schnabla w swoich „dziobatych" maskach i tym bardziej nie widać już kościotrupów. Chorzy leżą w szpitalach lub namiotach. Pielęgniarki i lekarze pracują w maskach podobnych do współczesnych. Także na ulicach pojawiają się zamaskowani przechodnie. W tej epoce pojawiły się pierwsze szczepionki, a z nimi zobaczyć można sceny ze szczepień. Dokumentacja fotograficzna hiszpanki, największej epidemii w dziejach, jest już bardzo duża i bardzo przerażająca (fot. 16).

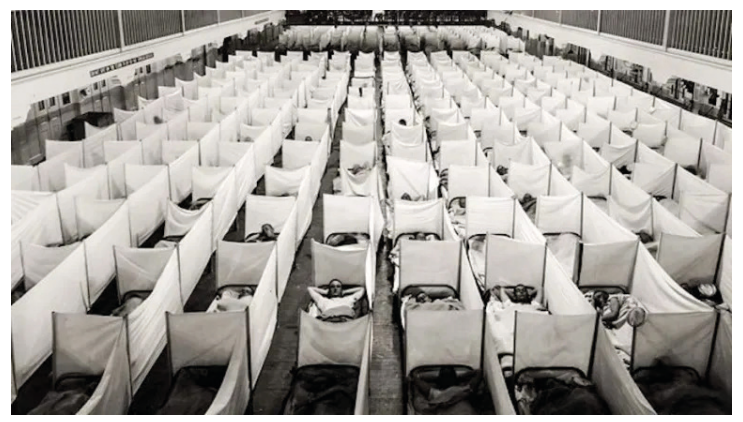

Fotografia 16. Szpital polowy dla chorych na grypę hiszpankę Źródło: Historia bez tabu (2021)

\section{Skutki pandemii w krajobrazie miast, miejsc zabytkowych i terenów chronionych}

Lockdown to słowo, które weszło do powszedniego użytku również w Polsce w związku ze współczesną pandemią koronawirusa. Zakaz opuszczania domu, czy też określonej strefy to podstawowa przyczyna zmian w krajobrazie wywołanych pandemią. Lockdown zmienił krajobrazy miasta i wielu obszarów krajobrazu naturalnego i kulturowego, zwłaszcza miejsc nawiedzanych masowo przez turystów. W Krakowie - mieście żyjącym z turystyki, niemal okrągły rok, podczas lockdownu krajobraz zmienił się zasadniczo. Ulice i place normalnie wypełnione ludźmi nagle opustoszały. Dla mieszkańców Krakowa, żyjących od wielu lat w tym mieście, była to pierwsza w życiu okazja zobaczenia np. Rynku Głównego, ul. Floriańskiej czy Wzgórza Wawelskiego bez ludzi (fot. 17). Ponieważ w starym mieście w ostatnim 20-leciu nastąpiła zmiana funkcji - kamienice straciły stałych mieszkańców, urzędy przeniosły się poza śródmieście. W to miejsce wprowadzono obsługę ruchu turystycznego 


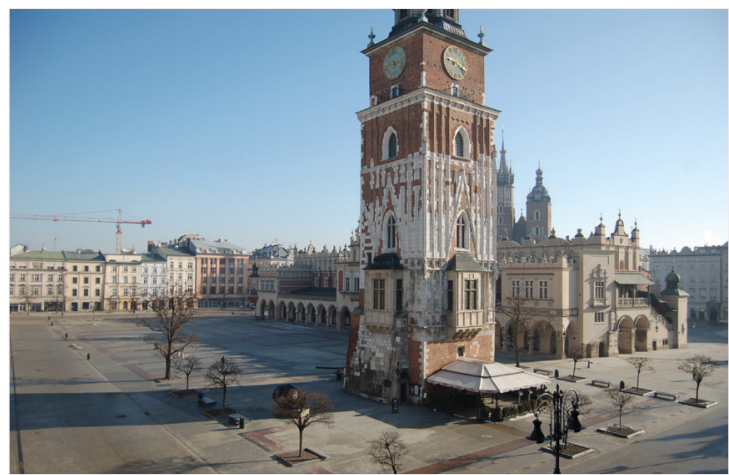

Fotografia 17. Pusty rynek krakowski podczas pandemii COVID-19

Źródło: D. Czapczyńska

oraz usługi kultury. Hotele, restauracje, muzea i sklepy przestały działać podczas lockdownu, co spowodowało znaczne ograniczenie wieczornego i nocnego oświetlenia. Miasto stało się puste i ciemne. Ludzie nie umierają już na ulicach i placach, tak jak to było w dawnych wiekach. Nie ma stosów palących się trupów, jak u Homera. Chorzy leczą się w szpitalach i w domach. Niemniej obraz pustego miasta jest dziwny i przygnębiający.

Wprawdzie lockdown nie trwał tak długo, aby odpowiedź przyrody na zmiany funkcjonowania przestrzeni miasta były wyraźnie widoczne, ale jednak kępy trawy pojawiające się w szparach między płytami chodnikowymi czy w pęknięciach asfaltu przypominaja że przyroda może wkroczyć w najmniejszą nawet lukę w skorupie, którą stwarza utwardzona w coraz większym stopniu powierzchnia miasta (fot. 18, 19).

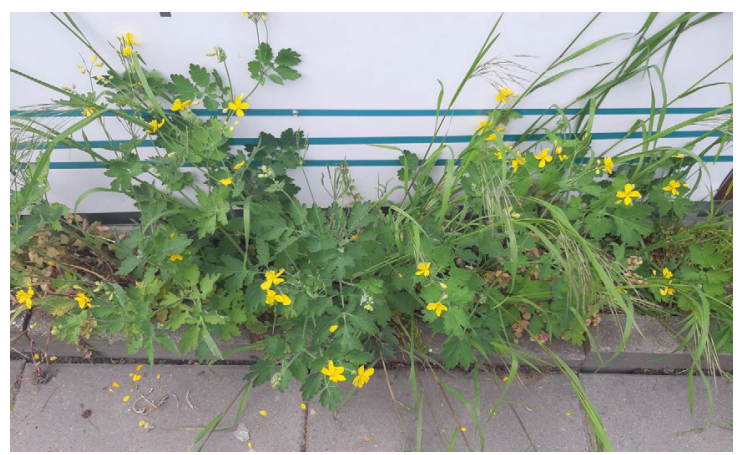

Fotografia 18. Przyroda atakuje „skorupę" powierzchni miasta Źródło: K. Fabijanowska 


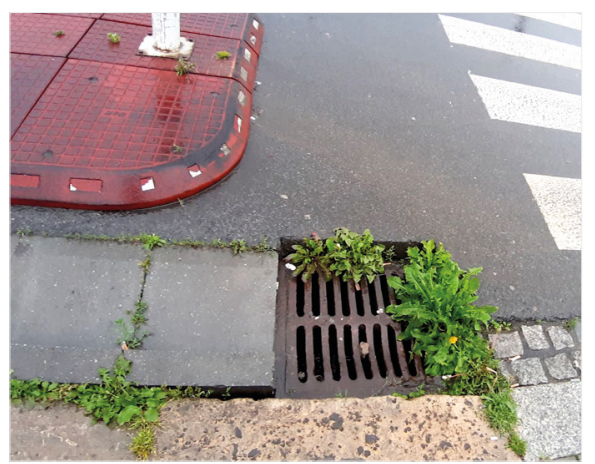

Fotografia 19. Przyroda atakuje „skorupę” powierzchni miasta Źródło: K. Fabijanowska

Do miast nieśmiało wkraczają także dzikie zwierzęta, których dawno tam nie było: dziki, sarny, jelenie, kozy, dzikie koty. Na razie, gdy jest ich mało, budzą zainteresowanie i sympatię. Stali zwierzęcy mieszkańcy umacniają swoje miejskie siedliska (fot. 20).

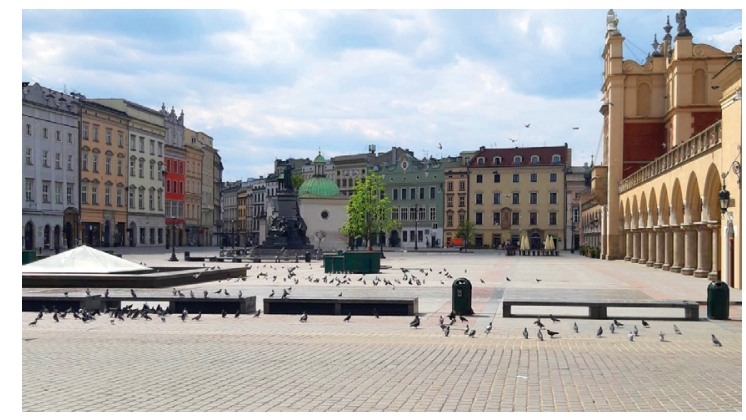

Fotografia 20. Krakowski rynek pod władaniem gołębi w czasie pandemii COVID-19

Źródło: K. Fabijanowska

Brak turystów zmienił sytuacje w miejscach miejsc o dużych walorach zabytkowych, w miejscowościach wypoczynkowych, na szlakach turystycznych, w terenach przyrodniczo chronionych. Są wśród nich takie miejsca, gdzie liczba turystów przed pandemią przekroczyła znacznie sensowną normę, pozwalającą podtrzymać wartość przyrodniczą i kulturową tych miejsc i korzystać bez przeszkód z tych walorów. Dla tych miejsc nagły odpływ turystów jest swoistym odpoczynkiem od nadmiernej eksploatacji, zwanej potocznie zadeptaniem (fot. 21-26). Próby odwołania lockdownu dowodzą jednak, że zahamowane na krótko potrzeby zaspakajane przez 
turystykę wybuchają natychmiast ze zdwojoną siła, niwecząc korzyści, jakie niósł ten krótkotrwały „odpoczynek”. Doświadczenie lockdownu pokazują także, jak szybko następują straty w infrastrukturze turystycznej. Czy i jak szybko da się je odrobić, oczywiście nie wiadomo.

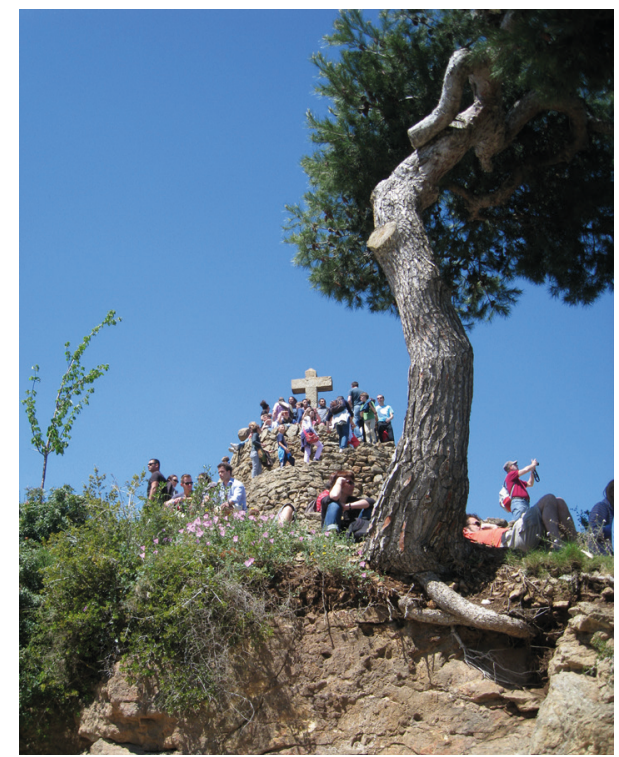

Fotografia 21. Kalwaria

w Parku Güell w Barcelonie

- zabytek zadeptywany przez turystów Źródło: K. Pawłowska

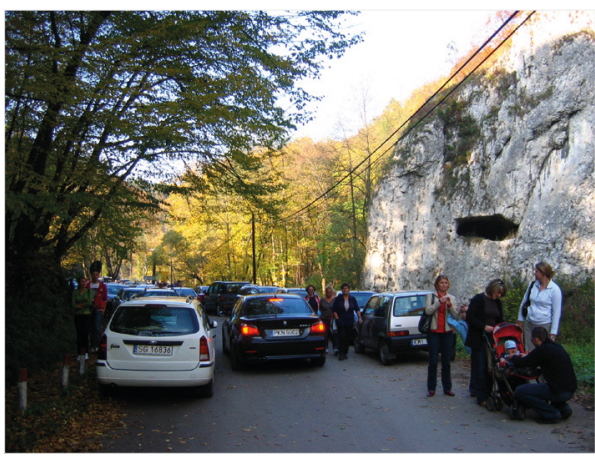

Fotografia 23. Oblegany

Ojcowski Park Narodowy przed pandemią Źródło: J. Partyka

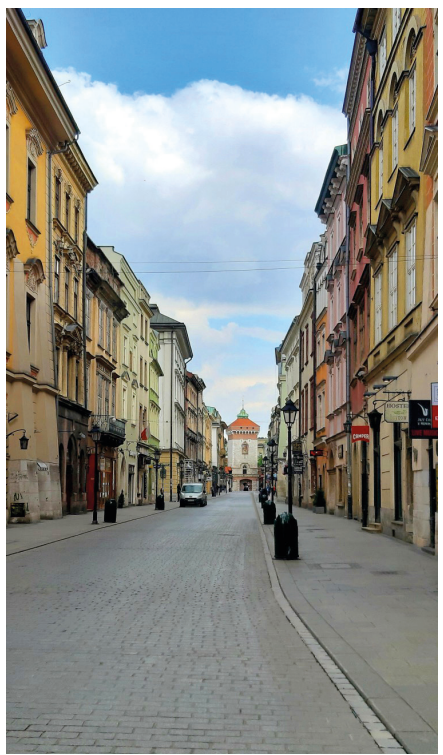

Fotografia 22. Pusta

ul. Floriańska w Krakowie $\mathrm{w}$ czasie pandemii w $2020 \mathrm{r}$. Źródło: K. Fabijanowska

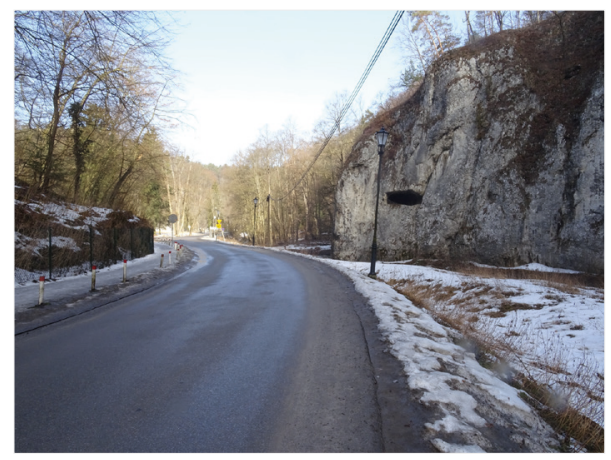

Fotografia 24. „Odpoczynek” przyrody w Ojcowskim Parku Narodowym podczas pandemii Źródło: J. Partyka 


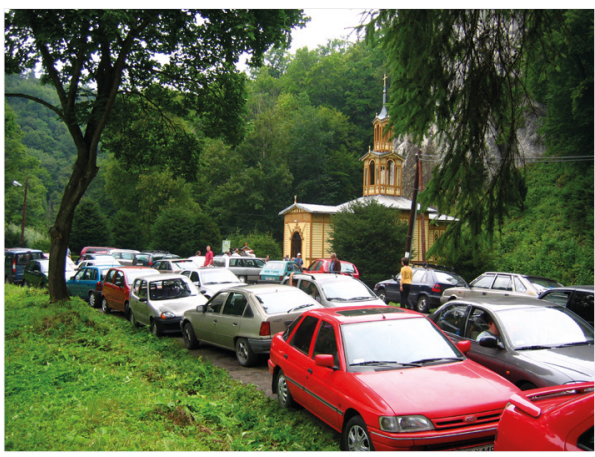

Fotografia 25. Tłok w Ojcowskim

Parku Narodowym przed pandemią Źródło: J. Partyka

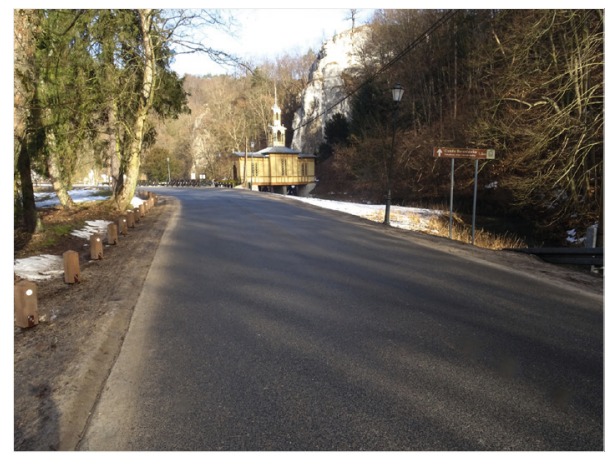

Fotografia 26. Brak turystów w Ojcowskim Parku Narodowym podczas pandemii Źródło: J. Partyka

\section{Pouczające doświadczenia pandemii}

Okres roku, jaki przeżyliśmy w Polsce $\mathrm{w}$ warunkach pandemii przyniósł $\mathrm{w}$ wielu dziedzinach doświadczenia, które powinny być pouczające. Namysł nad formami życia po pandemii staje się coraz ważniejszym składnikiem refleksji nad przyszłością twórców cywilizacji, kultury i polityki. Jest on poważnie utrudniony faktem, że nie wiadomo, jak długo trwać będzie pandemia i do jakiego stopnia da się ją pokonać.

Zmiany w krajobrazie powstałe $w$ czasach pandemii po jej hipotetycznym zakończeniu z pewnością nie znikną bez śladu tak, jakby ich nigdy nie było. Na tyle na ile krajobraz zależny jest od bieżącej sytuacji, jego formy zmieniać się będą pod dyktando tego postpandemiczne go życia.

Jedno z ważnych pytań dotyczy turystyki. Czy jej rozmiary i formy w życiu społecznym, ekonomicznym, kulturalnym ludzkości, ale i w kontekście stanu natury, nie wymagają rewizji. Podczas lockdownu okazało się, jak bardzo jednostronny i ryzykowny jest niczym nie hamowany rozwój zagospodarowania i użytkowania wielu miejsc na świecie, uzależnionych niejako od turystyki.

Są to pytania, na które obecnie trudno odpowiedzieć, ale zapewne warto zbierać informacje i obserwacje z niecodziennego czasu pandemii, porządkować je, aby tworzyć grunt pod konstrukcje nowego życia. 


\section{Krajobraz dźwiękowy w czasach zarazy}

Na koniec uwagi dotyczące krajobrazu dźwiękowego (Bernat, 2008; Pawłowska, 2012). Cisza, dawno nie spotykana cisza, to jeden z ważnych przejawów współczesnego lockdownu. Lecz, gdy spróbujemy zrekonstruować krajobraz dźwiękowy zarazy z przeszłości, usłyszymy zapewne nie tylko jęki chorych, lecz także pieśni błagalne ludzi proszących o zmiłowanie Boga i świętych. Najpiękniejszą z nich, są zapewne suplikacja Święty Boże! $!^{2}$ - pieśń powalająca ludzi na kolana i mocno inspirująca artystów, między innymi Jana Kasprowicza (Kasprowicz, 1922), Stanisława Przybyszewskiego i Władysława Orkana (fot. 27).

Znacznie mniej ponure nastroje niesie inna melodia, znana w całej Europie, Och du liber Augustin ${ }^{3}$, to niemieckojęzyczna śpiewka ludowa, niosąca z sobą legendę związaną z epidemią (fot. 28). Augustyn był wiedeńskim śpiewakiem ludowym i kobziarzem. Był powszechnie znany i lubiany. Gdy w 1679 r. wybuchła we Wiedniu epidemia dżumy, Augustyn nie zaprzestał swojej rozrywkowej działalności. W stanie upojenia alkoholowego wpadł wraz ze swoją kobzą do dołu z trupami. Gdy oprzy tomniał, zaczął grać na kobzie, przywołując w ten sposób pomoc.

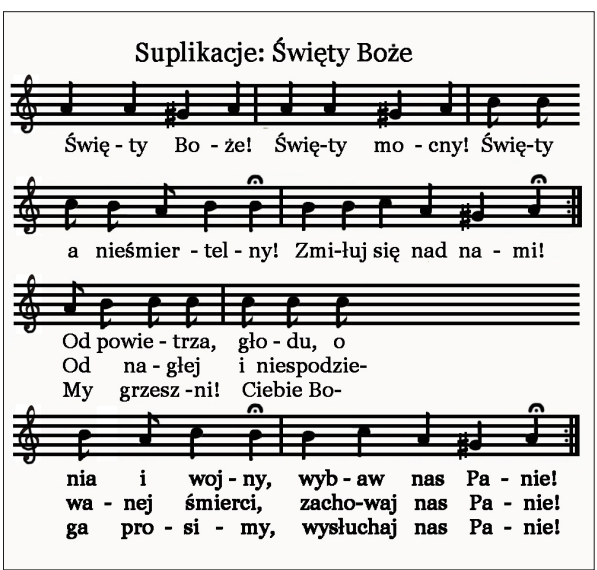

Fotografia 27. Nuty suplikacji Święty Boże

Źródło: YouTube (2021)

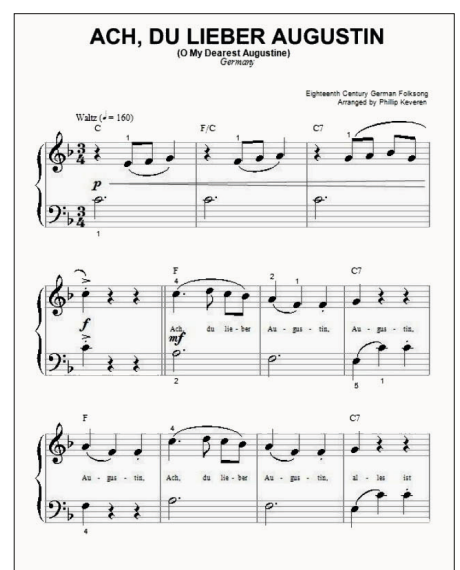

Fotografia 28. Nuty piosenki o Augustynie Źródło: Wikipedia (2021f)

\footnotetext{
${ }^{2}$ Nagranie audio pieśni do odsłuchania na portalu YouTube: https://www.youtube. com/watch? v=P1mSZaDgej8 (26.02.2021).

${ }^{3}$ Nagranie audio piosenki do odsłuchania na portalu YouTube: https://www.youtube. com/watch?v=TE4M7nu2xlY (26.02.2021).
} 
Nie mógł bowiem wygrzebać się z dołu o własnych siłach. Pomoc nadeszła i okazało się, że Augustyn mimo, że przespał się z trupami, wcale się nie zaraził. Przypuszczano, że tak się stało, bo Augustyn był pijany.

Polskie tłumaczenie słów piosenki Och du liber Augustin brzmi jak następuje:

O mój miły Augustynie, Augustynie, Augustynie, Wszystko minie, wszystko minie.

Oby była to dobra wróżba na lata dwudzieste XXI w.

\section{Bibliografia}

Asklepiejon na Kos (2021). Pobrane z: https://zwiedzo-maniacy.pl/asklepiejon-na-kos (25.02.2021).

Bernat, S. (2008). Dźwięk w krajobrazie jako przedmiot badań interdyscyplinarnych. Prace Komisji Krajobrazu Kulturowego PTG, 11, 1-320.

Defoe, D. (1993). Dziennik roku zarazy. Warszawa: Wydawnictwo Puls.

Fineartamerica (2021). Pobrane z: https://fineartamerica.com/ (24.02.2021).

Grekoman (2021). Pobrane z: http://www.grekoman.ru/catalog/asklepion-ostrov-kos (25.02.2021).

Historia bez tabu (2021). Pobrane z: https://blogbeztabu.blog/2020/03/18/grypa-hiszpanka-najniebezpieczniejsza-pandemia-w-historii-swiata/ (24.02.2021).

Homer (1804). Iliada. Pobrane z: https://wolnelektury.pl/katalog/lektura/homer-iliada. html (23.02.2021).

Kasprowicz, J. (1922). Hymny, Święty Boże, Święty Mocny! Pobrane z: https://wolnelektury. $\mathrm{pl} /$ katalog/lektura/hymny-swiety-boze-swiety-mocny.html (3.03.2021).

Krukowski, K. (2020). Obraz zarazy. Pobrane z: https://www.youtube.com/ watch?v=z32uDgzfsr8 (25.02.2021).

Myga-Piątek, U. (2001). Spór o pojęcie krajobrazu w geografii i dziedzinach pokrewnych. Przeglad geograficzny, 73 (1-2), 165-176. Pobrane z: https://www.researchgate.net/publication/299847823_Spor_o_pojecie_krajobrazu_w_geografii_i_dziedzinach_pokrewnych (3.03.2021).

Niezależna (2021). Pobrane z: https://niezalezna.pl/338060-sw-roch-odwiedzajacy-chorych-altomontego-barokowe-arcydzielo (25.02.2021).

Pawłowska, K. (2012). Dźwięk w krajobrazie jako przedmiot badań i środek wyrazu w sztuce ogrodowej i architekturze krajobrazu. Audiosfera miasta. Prace Kulturoznawcze, 13, 31-56. Pobrane z: https://wuwr.pl/pkult/article/view/5357?source=/pkult/article/ view/5357 (25.02.2021).

Sznajderman, M. (1994). Zaraza. Mitologia dżumy, cholery i AIDS. Warszawa: Wydawnictwo Naukowe Semper.

Tukidydes (1957). Wojna peloponeska. Pobrane z: http://biblioteka.kijowski.pl/antyk\%20 grecki/\%20tukidydes\%20-\%20wojna\%20peloponeska.pdf (23.02.2021).

Wudarki, Ł. (2020). E-Sztuka w Artusie; Obrazy na czas zarazy. Pobrane z: https://artus.torun. pl/events/e-sztuka-obrazy-na-czas-zarazy/ (25.02.2021). 
Wyka, K. (1968). Modernizm polski. Kraków: Wydawnictwo Literackie. Pobrane z: https:// wolnelektury.pl/katalog/lektura/wyka-modernizm-polski.html (3.03.2021).

Wikimedia Commons (2021). Pobrane z: https://commons.wikimedia.org/wiki/ File:Paul_F\%C3\%BCrst,_Der_Doctor_Schnabel_von_Rom_(Holl\%C3\%A4nder_version).png (23.02.2021).

Wikipedia (2021a). Pobrane z: https://pl.wikipedia.org/wiki/Plik:Apollo_razi_grotami_pomoru.jpg (23.02.2021).

Wikipedia (2021b). Pobrane z: https://pl.xcv.wiki/wiki/Woodcut (23.02.2021).

Wikipedia (2021c). Pobrane z: https://pl.wikipedia.org/wiki/Rozalia_z_Palermo (23.02.2021).

Wikipedia (2021d). Pobrane z: https://pl.wikipedia.org/wiki/Triumf_\%C5\%9Bmierci_ (obraz_Pietera_Bruegla_starszego) (24.02.2021).

Wikipedia (2021e). Pobrane z: https://pl.wikipedia.org/wiki/Taniec_\%C5\%9Bmierci (24.02.2021).

Wikipedia (2021f). Pobrane z: https://en.wikipedia.org/wiki/O_du_lieber_Augustin (26.02.2021).

Wikiwand (2021). Pobrane z: https://www.wikiwand.com/pl/Wyspa_Tyberyjska (23.02.2021).

YouTube (2021). Pobrane z: https://www.youtube.com/watch?v=TE4M7nu2xlY (26.02.2021).

\section{KRAJOBRAZY ZARAZY}

Abstrakt: Od roku trwa pandemia powodowana przez koronawirusa Covid-19. Niespodziewanie życie ludzi na całym świecie zmieniło się diametralnie. W związku z tym zmieniają się także krajobrazy zarówno naturalne, jak i kulturowe. Nikt nie wie, jak długo będzie trwać to inne, pandemiczne życie i jak będą wyglądać czasy postpandemiczne. Niecodzienne doświadczenia czasów pandemii powinny być pouczające. Dlatego wydaje się, że warto je gromadzić i porządkować, by tworzyć podstawy do namysłu nad przyszłością.

Artykuł ten jest próbą naszkicowania problematyki zmian w krajobrazie, jakie przynosi pandemia, poprzedzoną refleksją nad śladami i konsekwencjami poprzednich epidemii, zapisanymi w sztuce i pozostawionymi w krajobrazie. Lista pytań, jakie można by zadać na podstawie doświadczenia pandemii nie jest tu z pewnością kompletna. Nie ma tu odpowiedzi nawet na te wszystkie pytania, które zostały tu zadane. Tekst nie jest zatem relacją z badań lecz raczej zaproszeniem do dyskusji.

Miejsca, których krajobraz zmieniła pandemia, są liczne, ale bodaj największe ze zmian dotyczą miejsc turystycznych, skąd na jakiś czas zniknęli zwiedzający. Debata nad rozmiarami i formami ruchu turystycznego może i powinna korzystać z tych doświadczeń.

Słowa kluczowe: pandemia, krajobraz, lockdown, zmiana, turystyka.

\section{EPIDEMIC LANDSCAPES}

Abstract: The Covid-19 coronavirus pandemic has continued for a year. Unexpectedly, the lives of people all over the world have changed dramatically. Consequently, landscapes, both natural and cultural, are also changing. Nobody knows how long the pandemic life will last and what the post-pandemic world will be like. Extraordinary pandemic experiences should be enlightening. Therefore, it seems worthwhile collecting and organizing them in order to create a basis for reflection in the future. 
The article is an attempt to sketch the issues of changes in the landscape caused by the pandemic, preceded by a reflection on the traces and consequences of earlier epidemics written in art and left in the landscape. The list of questions that could be asked here from the experience of the pandemic is certainly not exhaustive and not all the questions asked are answered. The text is therefore not a research report, but rather an invitation to discussion.

There are many places whose landscape has been changed by the pandemic, but perhaps the biggest concern tourist destinations from which tourists have disappeared. The debate on the scale and form of tourism can and should benefit from these experiences.

Keywords: pandemic, landscape, lockdown, change, tourism. 